\title{
THE IMPACT OF SOYBEAN AND CORN INTERCROPPING SYSTEM AND SOIL FERTILITY MANAGEMENT ON SOYBEAN APHID POPULATIONS APHIS GLYCINES (HEMIPTERA: APHIDIDAE) AND SOYBEAN GROWTH PERFORMANCE
}

\author{
Rosma Hasibuan ${ }^{1} \&$ Jamalam Lumbanraja ${ }^{2}$ \\ ${ }^{1}$ Department of Plant Protection, College of Agriculture, University of Lampung \\ E-mail: rosma@unila.ac.id \\ ${ }^{2}$ Department of Soil Science, College of Agriculture, University of Lampung \\ J1. Prof. Sumantri Brojonegoro No 1 Bandar Lampung, Indonesia
}

\begin{abstract}
The impact of soybean and corn intercropping system and soil fertility management on soybean aphid populations Aphis glycines (Hemiptera: Aphididae) and soybean growth performance. Agricultural management cropping systems play an important role in affecting a crop plant's ability to tolerate or resist insect pests. Field studies were conducted to examine the effect of two strategies management systems: fertilizer treatment and intercropping soybean with corn on soybean aphid (Aphis glycines Matsumura) population and soybean growth and yield parameters. The intercropping treatments were: soybean alone; 2:1 soybean/corn intercrop; and 3:1 soybean/corn intercrop. While the soil fertility treatments were the combination of NPK (urea $100 \mathrm{~kg} \mathrm{ha}^{-1}+$ SP-36 $\left.200 \mathrm{~kg} \mathrm{ha}^{-1}+\mathrm{KCl} 200 \mathrm{~kg} \mathrm{ha}^{-1}\right)$ levels, dolomite $(4$ ton ha-1), compost $(10$ ton ha$\left.{ }^{1}\right)$, and chicken manure (10 ton $\left.\mathrm{ha}^{-1}\right)$. The results of the first study showed that the intercropping soybean with corn significantly reduced the population density of soybean aphids. However, there were no significant effects of intercropping systems on soybean growth (plant height) and yield (number seed per pod and thousand seed weight) performances except on the number of soybean pods per plant. Meanwhile, the result of the second study indicated that soil fertilizer treatments had a significant effect on the soybean plant characteristics: leaf numbers; pod numbers; and plant height. Combining intercropping methods and soil fertilizer management offer an opportunity to protect the soybean plants by natural and sustainable pest management.
\end{abstract}

Key words: Aphis glycines, soybean aphid, fertilizer management, intercropping system

\begin{abstract}
ABSTRAK
Dampak sistem tumpang sari kedelai-jagung dan pengelolaan kesuburan tanah terhadap kepadatan populasi kutu daun, Aphis glycines (Hemiptera: Aphididae)dan pertumbuhan tanaman kedelai. Sistem pengelolaan tanam pertananian mempunyai peranan penting dalam hal mempengaruhi kemampuan tanaman untuk mentolerir maupun bertahan dari serangan hama. Dua percobaan lapang tentang strategi pengelolaan tanam telah dilakukan: pengelolaan pupuk dan tumpangsari kedelai dengan jagung terhadap pertumbuhan populasi kutu daun (Aphis glycines Matsumura) dan parameter pertumbuhan vegetatif dan generatif tanaman kedelai. Perlakuan tumpangsari adalah: kedelai monokutur; tumpangsari 2:1 kedelai/jagung, dan tumpangsari 3:1 kedelai/jagung. Sementara perlakuan pengelolaan kesuburan tanah adalah kombinasi pupuk NPK (urea $\left.100 \mathrm{~kg} \mathrm{ha}^{-1}+\mathrm{SP}-36200 \mathrm{~kg} \mathrm{ha}^{-1}+\mathrm{KCl} 200 \mathrm{~kg} \mathrm{ha}^{-1}\right)$, kapu rdolomit (4 ton ha $\left.{ }^{-1}\right)$, kompos (10 ton ha- ${ }^{-1}$, dan kotoran ayam (10 ton $\left.\mathrm{ha}^{-1}\right)$. Hasil penelitian pertama menunjukkan bahwa tumpangsari kedelai dengan jagung secara nyata dapat menurunkan kepadatan populasi hama kutu daun kedelai. Namun, tidak ada pengaruh nyata dari sistem tumpangsari terhadap pertumbuhan vegetatif tanaman kedelai (tinggi tanaman) dan pertumbuhan generatif (jumlah biji per polong dan berat seribu biji) kecuali pada jumlah polong per tanaman kedelai. Sementara itu, hasil percobaan kedua menunjukkan bahwa perlakuan pupuk berpengaruh nyata terhadap pertumbuhan tanaman kedelai: jumlah daun, jumlah polong, dan tinggi tanaman. Memadukan dua strategi sistem pengelolaan tanaman yaitu tumpang sari dan pengelolaan kesuburan tanah memberikan peluangn untuk melindungi tanaman kedelai melalui pengelolaan hama alami dan berkelanjutan.
\end{abstract}

Kata kunci: Aphis glycines, kutu aphis kedelai, pengelolaan kesuburan, sistem tumpangsari 


\section{INTRODUCTION}

Soybean Glycine max (L.) Merrill is one of the most important cultivated crops worldwide. In Indonesia, soybean has been planted as a source of protein and essential amino acids and has been utilized broadly in the nutritional balance of the rural and urban Indonesian diet. Several pests are known to attack soybean plant start from early vegetative growth until harvesting (Hill et al., 2001; Irwin et al., 2000). One of important pest of soybean known in Indonesia is the soybean aphid, Aphis glycines Matsumura (Hemiptera: Aphididae) (van den Berg et al., 1997). This pest is commonly found throughout soybean-growing regions. Previous studies reported that soybean plants that severely infested by soybean aphids may be stunted or turned brown and die (Alleman et al., 2002; Clark \& Perry, 2002; Wang \& Ghabrial, 2002; Myers et al., 2005; Ragsdale et al., 2007; van den Berg et al., 1997). Besides directly feeding on soybean and causing yield reduction, $A$. glycines also threatens the productivity of soybean, because it is an important virus vector (Clark \& Perry, 2002; Halbert et al., 1986). A study by McCornack et al. (2008) reported that soybean yield reductions up to $40 \%$ was occurred when aphid infestations were heavy. Moreover Wang \& Ghabrial (2002) found that soybeanseed yields were reduced by $27.8 \%$ and plant height decreased by $20.2 \mathrm{~cm}$ in aphid-infested plants as compared to that in non-infested plants.

Insecticides have been the primary pest management strategy used for soybean aphid control (Hodgson et al., 2010; Wang et al., 1993). Although use of insecticides can be a quick and easy way to control A. glycines, frequent applications of broad-spectrum pesticides can lead to the buildup of aphid resistance to chemicals and resulting in more chemicals being used with potentially severe environmental side effects (Altieri \& Nicholls, 2003). Excessive use of these chemicals in pest control generate ecological and toxicological problems including acute and chronic human pesticide poisoning, animal poisoning, the contamination of agricultural products, the destruction of beneficial natural enemies, and developing insecticide resistance in pests (Altieri \& Nicholls, 2003; Qu et al., 1987; Wang et al., 1993).

The various drawbacks of the use of insecticides for insect pests' control lead to the adoption of pest management strategies that are sustainable and environmentally sound (Altieri \& Nicholls, 2003; Hsu et al., 2009; Myers et al., 2005). Cultural control including soil fertilizer management and intercropping system is an important alternative pest management as compared to chemical control. Soil fertilizer management as a part of cultural control can impact the physiological susceptibility of crop plants to insect pests by either affecting the resistance of individual plant to attack or by altering plant acceptability to certain insect pests (Letourneau et al., 1996; Letourneau \& Goldstein, 2001). According to Ofori \& Stern (1987), intercropping is as a system where two or more crop species are grown in the same field at the same time during a growing season. Ecologically, intercropping is one of the ways to diversify the species populations in the field. Many studies have shown that vegetative diversity in the form of intercropping can result in reduced pest densities and increases the resistance of the environment (Jankowska, 2007; Risch, 1983; Russell, 1989; Theunissen \& Den Ouden, 1980). Intercropping system is a low-input and traditional agricultural practice and is important in many developing countries including Indonesia. Intercropping is an important cultural practice in pest management and is based on the principle of reducing insect pests by increasing the diversity of an ecosystem (Risch, 2005). Several studies indicate that diversification practices such as intercropping are beneficial because these practices reduce pest damage. Therefore, there is a need to develop soybean aphid management tools and strategies that do not solely rely on agrochemicals. In response to A. glycines problem, the field experiments were conducted to study the effects of two potential pest management components, intercropping systems and soil fertilizer management for the management of soybean aphids, A. glycines.

\section{MATERIALS AND METHODS}

The Intercropping Experiment. Field study was conducted to evaluate the effect of intercropping system on soybean characteristics and the abundance of soybean aphid A. glycines at the agriculture college are, the University of Lampung, from March to July 2010. The land was manually cleared and ridged with hoes. Prior to soybean planting, natural rhizobium-root nodules (from previous cultivated soybean fields) were introduced to the soil to ensure the optimal plant growth. An experiment was laid out under randomized complete block design on an area of $300 \mathrm{~m}^{2}(20 \times 15 \mathrm{~m})$ consisting 9 plots, representing 3 treatments (soybean monocrop, 2:1 soybean/corn intercrop, and 3:1 soybean/corn intercrop), and each treatment was replicated three times. Each plot size was $3 \mathrm{~m}$ x $4 \mathrm{~m}$ with 1-m spacing between plots.

In the monoculture treatment, soybean seeds (local variety Anjasmoro) were sown 3 seeds per hole 
in the whole plot at $15 \times 45 \mathrm{~cm}$ spacing rows. While in the 2:1 soybean/corn treatment, two rows of soybean was sown at $45 \mathrm{~cm} \times 15 \mathrm{~cm}$ within one row of corn that was spaced at $90 \mathrm{~cm}$ by $30 \mathrm{~cm}$. The $3: 1$ soybean/corn intercrop treatment was three rows of soybean (spaced at $40 \mathrm{~cm} \times 10 \mathrm{~cm}$ ) between one row of corn at $120 \mathrm{~cm}$ by $30 \mathrm{~cm}$ spacing. For each treatment, soybean and corn was planted at the same time. A recommended dose of fertilizer (NPK urea $100 \mathrm{~kg} \mathrm{ha}^{-1}+$ SP-36 200 $\mathrm{kg} \mathrm{ha}^{-1}+\mathrm{KCl} 200 \mathrm{~kg} \mathrm{ha}^{-1}$ ) was applied at the time of sowing for both monocropping and intercropping plots. No insecticides were applied and weeds were removed manually. The field was irrigated daily as required, depending on weather conditions and plant demands. Five individual plants were randomly chosen from the middle rows of each experimental unit and labeled for recording the various observations. Sampling and recording soybean aphid population were done from each respective plot at weekly intervals. Whereas, soybean plant height was assessed only at seven weeks after planting (full bloom stage $=\mathrm{R} 1$ ); and soybean yield data (number of pods per plant; number of seeds per pod; weight of 1000 seeds) were recorded at harvest.

Soil Fertilizer Experiment. Another field trial was also conducted at the Agriculture College field, the University of Lampung, from June to November 2010 to determine the effect of soil fertilizer treatment on soybean aphid population and soybean growth parameters. The plot area used was $300 \mathrm{~m}^{2}(20 \times 15$ $\mathrm{m})$. The field was ploughed and then the soil was leveled and ridged mechanically in order to prepare suitable plots. The treatments were arranged in plots, each measuring of $2 \times 1.5 \mathrm{~m}$ with $0.5 \mathrm{~m}$ furrows spacing. The soybean variety used in this experiment was Anjasmoro (local variety). Prior to planting, natural rhizobium-root nodules (from previous cultivated soybean fields) were introduced to the soil to ensure the optimal plant growth. Soybean was planted in $15 \times 45 \mathrm{~cm}$ spacing rows by placing three seeds per hole. Two weeks later (Vc stage as described by Fehr and Caviness (1977), each hill was thinned to two seedlings per stand. The treatments consist of the following soil fertilizer amendments: $\mathrm{T} 1=100 \%$ Recommended Dose of Fertilizer $(\mathrm{RDF}=$ NPK urea $100 \mathrm{~kg} \mathrm{ha}^{-1}+$ SP-36 $200 \mathrm{~kg} \mathrm{ha}^{-1}+\mathrm{KCl} 200$ $\left.\mathrm{kg} \mathrm{ha}^{-1}\right) ; \mathrm{T} 2=75 \% \mathrm{RDF}+$ Recommended Dose of Compost $\left(\mathrm{RDC}=\right.$ compost rate $=20$ ton ha $\left.{ }^{-1}\right) ; \mathrm{T} 3=$ $50 \% \mathrm{RDF}+50 \% \mathrm{RDC}+$ Dolomite $(\mathrm{Dol}=$ dolomite rate $=4$ ton ha ${ }^{-1} ; \mathrm{T} 4=50 \% \mathrm{RDF}+50 \% \mathrm{RDC}+$ Chicken Manure $\left(\mathrm{CM}=\right.$ chicken manure rate $=10$ ton $\left.\mathrm{ha}^{-1}\right)$. The treatments were arranged in the Randomized
Complete Block Design (RCBD) and each treatment was replicated three times. The plots were maintained with no insecticide application and were hand weeded periodically. As in the first trial, the field was irrigated daily as required, depending on weather conditions and plant demands.

As soybean plants reached the V2 stage (three weeks after planting), plants were artificially infested with soybean aphid, A. glycines (Hemiptera: Aphididae). Soybean aphids used in this study were from a laboratory colony which previously collected from soybean fields. After aphid infestation, ten plants were selected randomly from each as a sample site. Every week, each sample plant was visually examined, and number of soybean aphid and natural enemies were counted and plant phenology was recorded using the method by Fehr et al. (1971). Seven weeks after planting (full bloom stage $=\mathrm{R} 1$ ), the height of each sample plant was measured and numbers of leaves per plant were also recorded. At the end of sampling period, the number of pods per plant, and the number seeds per pod were recorded.

Data Analysis. For intercropping system experiment, means and standard errors (SEs) for soybean aphid densities; plant height, pod numbers per plant, seed numbers per pod; and 100 seed weight were calculated and also were analyzed by analysis of variance (ANOVA) (PROC GLM procedure) followed by comparisons of means by the Fisher protected least significant difference (LSD) test (significance level, $P$ $=0.05)($ SAS, 2004). Moreover, the effect of intercropping systems on the common mean (averaged across sampling periods) of soybean aphid densities was presented graphically. For soil nutrition experiment, means and SEs were assessed for soybean aphid densities, the plant performance (plant height, leaf numbers, pod numbers, and dry weight/plant. The effects of soil fertilizer treatments were analyzed by analysis of variance (ANOVA) (PROC GLM procedure) followed by comparisons of means by the Fisher protected least significant difference (LSD) test (significance level, $P=0.05$ ) (SAS, 2004). As in the first study, the common mean (averaged across sampling periods) of soybean aphid densities among soil fertilizer treatments was also presented graphically. In addition, a linear correlation analysis (PROG CORR procedure) using the SAS program was performed to relate soybean aphid densities to soybean growth parameters (plant height, leaf numbers, pod numbers) (SAS, 2004). 


\section{RESULTS AND DISCUSSION}

Intercropping Experiment. The results of studies on the effect of intercropping soybean with corn on the aphid (Aphis glycines Matsumura) population are presented in Table 1 and Fig, 1 . This study revealed that the population of soybean aphids (assessed by direct count) was fluctuated and varied across different intercropping systems for all sampling periods (Table 1). The aphid densities on soybean monoculture, 2:1 soybean/corn intercrop, and 2:1 soybean/corn intercrop changed over sampling periods and ranged from a mean of $7.33-192.00 ; 6.33-99.00 ; 6.00-90.00$ aphids per plant, respectively. There were no significant differences between the intercropping treatments in soybean aphid population on the four early sampling periods. However, the significant effect of these intercropping systems on the population of A. glicynes was observed on the fifth; sixth; seventh; and eighth sampling periods with $\mathrm{F}$ value and significance level of $F_{2.6}=15.56, p<0.0037 ; F_{2.6}=$ $31.79, p<0.0001 ; F_{2.6}=29.43, p<0.001 F_{2.6}=10.32$, $p<0.0210$, respectively. The results further revealed that soybean aphid densities grown in 2:1 soybean/corn intercrop and 3:1 soybean/corn intercrop was significantly lower compare to those sole soybean.

Similar results were also shown on data over the course of the experiment in which soybean aphid density in 3:1 soybean/corn intercrop and 3:1 soybean/corn intercrop had a mean (means are averaged over sampling periods) of 52.44 and 48.00 aphids per plant, respectively, and this density was significantly lower compared to the soybean monoculture (77.91 aphids/ plant) (Fig. 1).

This finding was supported by other workers who have shown that insect pest populations are often reduced in intercropping system (Jankowska, 2007; Mensah, 1997; Risch, 1983; Russell, 1989; Theunissen et al., 1980). Moreover, Andow (1991) who analyzed 209 studies involving 287 pest species indicated that the population of pest insects on intercropping system was lower in $52 \%$ of the studies (149 species) compared with monocultures. Other previous study indicated that oviposition and emigration behavior of the leek moth (Lepidoptera: Acrolepiidae) and the diamondback moth (Lepidoptera: Plutellidae) was affected by intercropping system (Asman et al., 2001). Approximately similar results were reported in various published works as following: Booij et al. (1997) observed that intercropping cabbage with clover was effective in controlling ground beetles; Latheef et al. (1984) found that Phyllotreta cruciferae (Coleoptera: Chrysomelidae) populations significantly reduced on intercropping of collard plants; Theunissen \& Den Ouden (1980) recorded the effects of intercropping with Spergula arvensis on pests of Brussels sprouts, and Jankowska et al. (2009) concluded that the number of cabbage aphid Brevicoryne brassicae L. and flea beetles Phyllotreta was significantly lower on intercropping plots in comparison with homogenous crops. Moreover Oso \& Falade (2010) recorded that intercropping cowpea and maize appears to be a determinant factor for leaf infestation by insect pests. More recent works by Xie et al. (2012) indicated that intercropping wheat, Triticum aestivum L., with mung bean, Vigna radiate L suppresses English grain aphid, Sitobion avenae population growth and preserves the population of natural enemies of aphids and by Ramalho et al. (2012) showed that the fennel aphid, Hyadaphis foeniculi populations were significantly larger in sole fennel (Foeniculum vulgare) plots than in intercropped plots. In a more broad perspective Langer et al. (2007) and Mensah (1997) concluded that intercropping has a significant role in integrated pest management.

Lower pest density on intercropping systems may be due to the action of natural enemies in intercropping system on the natural enemy community. Diverse agroecosystem created by multiple cropping tend to increase numbers of natural enemies (Andow, 1991; Elton, 1958; Jankowska, 2007). Other previous study by Jankowska (2007) indicated that cabbage aphid parasitisation by Diaeretiella rapae was greater and the percentages of predatory Syrphidae to prey were more favorable on intercropping plots compared with the homogenous crops. Moreover Russell (1989) reported the enemies hypothesis and explained that predatory insects and parasitoids are more effective at controlling populations of herbivores in diverse systems of vegetation than in simple ones. Similar results by Bach (1980) noted that intercrops or more diverse systems tend to have high density of predators and parasitoids than mono crops, and hence lower insect infestation.

One of the mechanisms that might lead to reduced insect attack in intercropping systems is the Enemies Hypothesis (Vandermeer, 1989; Root, 1973; Elton, 1958). Diverse agroecosystem created by multiple cropping tend to increase numbers of natural enemies (Andow, 1991; Jankowska, 2007). Natural enemies are attracted to diverse systems of shelter and alternative prey. The conservation of natural enemy populations is important as they regulate pest populations and reduce the number of pesticide applications (Landis et al., 2000). Moreover, Vandermeer (1989) proposed the disruptive crop hypothesis to explain how vegetation diversity can directly affect herbivore populations. His hypothesis is 
Table 1. Mean \pm SE number of soybean aphid (Aphis glycines) per plant among intercropping system

\begin{tabular}{cccccc}
\hline \multirow{2}{*}{$\begin{array}{c}\text { Sampling } \\
\text { periods* }\end{array}$} & \multicolumn{5}{c}{ Mean aphids per plant } \\
\cline { 2 - 5 } & $\mathrm{A}^{* *}$ & $\mathrm{~B}$ & $\mathrm{C}$ & \\
\hline 1 & $7.33 \pm 0.753^{* * *} \mathrm{a}$ & $6.33 \pm 0.58 \mathrm{a}$ & $6.00 \pm 1.19 \mathrm{a}$ & 0.57 & 0.2780 \\
2 & $19.00 \pm 2.89 \mathrm{a}$ & $17.33 \pm 3.67 \mathrm{a}$ & $18.33 \pm 3.23 \mathrm{a}$ & 3.56 & 0.1770 \\
3 & $38.00 \pm 3.92 \mathrm{a}$ & $34.66 \pm 3.16 \mathrm{a}$ & $35.33 \pm 4.01 \mathrm{a}$ & 5.62 & 0.0804 \\
4 & $89.33 \pm 7.55 \mathrm{a}$ & $76.33 \pm 6.49 \mathrm{a}$ & $71.33 \pm 6.93 \mathrm{a}$ & 6.21 & 0.0704 \\
5 & $95.96 \pm 25.21 \mathrm{a}$ & $88.33 \pm 28.45 \mathrm{~b}$ & $82.66 \pm 30.07 \mathrm{~b}$ & 15.56 & 0.0037 \\
6 & $192.00 \pm 28.33 \mathrm{a}$ & $99.00 \pm 26.25 \mathrm{~b}$ & $90.00 \pm 22.21 \mathrm{~b}$ & 31.79 & $<0.0001$ \\
7 & $123.96 \pm 27.33 \mathrm{a}$ & $77.00 \pm 21.45 \mathrm{~b}$ & $63.66 \pm 19.37 \mathrm{~b}$ & 29.43 & $<0.0001$ \\
8 & $87.96 \pm 5.92 \mathrm{a}$ & $49.33 \pm 6.19 \mathrm{~b}$ & $46.33 \pm 5.92 \mathrm{~b}$ & 10.32 & 0.0210 \\
9 & $47.66 \pm 4.33 \mathrm{a}$ & $33.66 \pm 4.96 \mathrm{a}$ & $28.33 \pm 4.02 \mathrm{a}$ & 5.21 & 0.0915 \\
\hline
\end{tabular}

*Sampling occurred weekly and continued until harvest;

** Intercroping treatments: $\mathrm{A}=$ sole soybean, $\mathrm{B}=2: 1$ soybean/corn intercropping, $\mathrm{C}=3: 1$ soybean/corn intercropping

*** Values within the same row followed by the same letters are not significantly different at the 5\% significance level according to Fisher protected least significant difference (LSD) test.



Figure 1. Common mean number (averaged over sampling periods) of soybean aphids Aphis glycines, per plant on soybean monoculture and soybean-corn intercropping. Means bearing the same letter are not significantly different at the 5\% significance level according to Fisher protected least significant difference (LSD) test.

equivalent to Root's (1973) resource concentration hypothesis and stipulates that a second plant species disrupts the ability of an insect to efficiently attack its proper host.

In addition, numerous previous studies have indicated that the intercropping may have other benefits other than pest control. Besides an alteration in the host plant environment of intercropping systems that directly affect herbivore population dynamics, crop plants intercropping systems also have consequences for plant growth and yield performances. Herbert et al. (1984) and Wiley \& Osiru (1972) observed that corn yield was 
increased when corn intercropped with soybean. Moreover, Biabani et al. (2008) reported that two intercropped soybean cultivars improve the final seed yield. In general, Carruthers et al. (1998) reported that intercropping systems influence yield variables of the component crops, such as harvest index, hundred seed weight, number of reproductive organs and number of seeds, within each reproductive unit.

These previous works were in contrast with our findings that presented in Table 2. The result indicated that there was a non-significant effect of soybean/corn intercropping on soybean growth characteristic: plant height $(F=1.326$; df $=2.6 ; P<0.2119)$ (Table 2). Moreover, analysis of variance on soybean yield components showed that there was no significant effect on the number soybean seeds per pod $(F=1.8920 ; \mathrm{df}=$ 2.6; $P<0.1293)$ and thousand seed weight of soybean $(F=5.5740 ; \mathrm{df}=2.6 ; P<0.0845)$ when intercropped with corn at any soybean/corn ratio. However, the number of soybean pods per plant $(F=7.7850$; df $=$ $2.6 ; P<0.0345)$ was significantly higher when intercropped with corn. These results are somewhat in agreement with Herbert et al. (1984) who reported that pod number per plant was the most responsive component of soybean yield to changes in plant quality traits. Similarly, Biabani et al. (2008) and Whigham \& Bharati (1983) observed that the higher yield of soybean was obtained from plant grown in intercropping system. These findings are also in close conformity with those reported by Adeniyan \& Ayoola (2006) who found that yield performance of soybean planted at the same time with corn was better than sole soybean. However, these findings are contrasted with reports by other workers (Raji, 2007; Addo-Quaye et al., 2011; Hayder et al., 2003) who recorded that maize-soybean intercropping system significantly reduced soybean yield. In addition, Egbe (2010) explained that the yield reduction of the intercropped soybean might be associated with interspecific competition between the intercrop components for growth resources (light, water, nutrients, air). One explanation for the variation in results might be that different cultivars respond differently to various intercropping system such as planting pattern and planting dates

Soil Fertilizer Experiment. The results of second trial indicated that soil nutrient treatment had a significant impact on soybean aphid population. Soybean aphid densities varied significantly among the soil fertilizer treatments across sampling periods, except at the first sampling. The seasonal population densities of soybean aphid were significantly lower on soybean plants grown with organic fertilizer (treatment B $=\mathrm{NPK}+$ Compost; treatment $\mathrm{C}=\mathrm{NPK}+$ compost + dolomite; treatment $\mathrm{D}$ $=$ compost + chicken manure), compared with those on plants grown with only inorganic fertilizer (treatment A $=100 \%$ NPK). Mean number of soybean aphids in the treatment of only inorganic fertilizer; NPK + Compost; $\mathrm{NPK}+$ compost + dolomite; compost + chicken manure ranged from 5.33 - 267.96; 3.66 - 73.32; 3.70 - 64.00; $2.50-19.43$ per plant across all sampling periods, respectively (Table 3 ). Soybean aphid densities on plants fertilized with $100 \%$ recommended dose of inorganic fertilizer $(\mathrm{RDF}=\mathrm{NPK})$ significantly changed over time and peaked on the sixth sampling period with a mean of 267.96 aphids/plant. However, aphid densities declined slightly by the final sampling period with 192 aphids/ plant. The lowest numbers of soybean aphid throughout the 9-weeks experiment was that in the treatment of manure and compost with a peak of 17.33 aphids/plant on the sixth sampling period (Table 3).

Morever, significant soil fertilizer effects were also detected on common mean (means were averaged over sampling period) and is presented in Fig. 2. The results indicated that soil nutrient treatment had a significant impact on soybean aphid population $\left(\mathrm{F}_{3.8}=\right.$ 5.99; $P<0.0456)$. Soybean plants treated with $100 \%$ chemical fertilizer NPK $(\mathrm{RDF}=$ treatment 1$)$ were

Table 2. The effects of intercropping on soybean growth morphological and yield characteristics

\begin{tabular}{ccccc}
\hline Treatment & Plant Height $(\mathrm{cm})$ & Pods/plant & Seed s/pod & 1000 seed weight $(\mathrm{gr})$ \\
\hline Sole soybean & $47.80 \pm 3.49$ & $24.30 \pm 3.21 \mathrm{~b}^{*}$ & $2.0 \pm 1.39$ & $96.23 \pm 3.51$ \\
2:1 intercrop & $48.90 \pm 5.23$ & $25.83 \pm 3.85 \mathrm{ab}$ & $1.95 \pm 0.99$ & $102.34 \pm 3.59$ \\
$3: 1$ intercrop & $50.4 \pm 6.13$ & $27.67 \pm 3.17 \mathrm{a}$ & $1.70 \pm 0.56$ & $108.27 \pm 3.67$ \\
\hline F V alue & 1.3260 & 7.7850 & 1.8920 & 5.5740 \\
\hline Pr $>$ F & 0.1419 & 0.0345 & 0.1293 & 0.0845 \\
\hline
\end{tabular}

* Values within the same column followed by the same letters are not significantly different at the 5\% significance level accord ing to Fisher protected least significant difference (LSD) test. 
colonized by the highest aphid numbers (129.30 aphids/ plant), and this density was significantly higher compared with other treatments. In contrast, treatment $50 \% \mathrm{RDF}$ $+50 \%$ RDC + CM (treatment 4) supported the lowest number (8.8 aphids/plant) of soybean aphids (Table 4 ). Based on this result, it can be concluded that soil nutrient has an impact on nutritional elements in plant that subsequently can affect susceptibility of plants to insect pests.

Numerous studies have shown that the ability of a crop plant to resist or tolerate insect pests and diseases is tied to optimal physical, chemical and mainly biological

Table 3. Mean number of soybean aphids A. glycines per plant on four soil fertilizer treatments .

\begin{tabular}{|c|c|c|c|c|c|c|}
\hline \multirow{2}{*}{$\begin{array}{l}\text { Time of* } \\
\text { Sampling }\end{array}$} & \multicolumn{4}{|c|}{ Mean aphids per plant } & \multirow{2}{*}{$F$-value } & \multirow{2}{*}{$\mathrm{Pr} \geq \mathrm{FF}$} \\
\hline & $\mathrm{A} * *$ & B & $\mathrm{C}$ & $\mathrm{D}$ & & \\
\hline 1 & $5.33 * * *$ & 3.66 & 3.70 & 2.50 & 0.57 & 0.2780 \\
\hline 2 & $22.50 \mathrm{a}$ & $18.5 \mathrm{ab}$ & $14.82 \mathrm{~b}$ & $5.33 \mathrm{c}$ & 5.56 & 0.0037 \\
\hline 3 & $118.98 \mathrm{a}$ & $37.32 \mathrm{~b}$ & $22.66 \mathrm{c}$ & $7.25 \mathrm{~d}$ & 16.62 & 0.0004 \\
\hline 4 & $147.96 \mathrm{a}$ & $45.32 \mathrm{~b}$ & $39.00 \mathrm{bc}$ & $8.50 \mathrm{c}$ & 8.82 & 0.0029 \\
\hline 5 & $195.96 \mathrm{a}$ & $73.32 \mathrm{~b}$ & $29.32 \mathrm{c}$ & $12.50 \mathrm{~d}$ & 31.79 & $<0.0001$ \\
\hline 6 & $267.96 \mathrm{a}$ & $70.00 \mathrm{~b}$ & $64.00 \mathrm{~b}$ & $17.33 \mathrm{c}$ & 16.48 & 0.0003 \\
\hline 7 & $192.00 \mathrm{a}$ & $60.00 \mathrm{~b}$ & $48.00 \mathrm{c}$ & $11.33 \mathrm{~d}$ & 19.43 & $<0.0001$ \\
\hline 8 & $123.96 \mathrm{a}$ & $29.32 b$ & $32.66 \mathrm{~b}$ & $9.60 \mathrm{c}$ & 10.32 & 0.0021 \\
\hline 9 & $87.96 \mathrm{a}$ & $19.32 \mathrm{~b}$ & $22.00 \mathrm{~b}$ & $4.50 \mathrm{c}$ & 11.21 & 0.0015 \\
\hline
\end{tabular}

*Sampling were done weekly and continued until harvest.

** Soil fertilizer treatments : A = 100\% $100 \%$ Recommended Dose of Fertilizer (RDF) NPK (100 kg urea/ha + $200 \mathrm{~kg} \mathrm{SP}-36 / \mathrm{ha}+200 \mathrm{~kg} \mathrm{KCl} / \mathrm{ha}) ; \mathrm{B}=75 \% \mathrm{RDF}+$ Recommended Dose of Compost $(\mathrm{RDC}=20 \mathrm{ton} / \mathrm{ha}) ; \mathrm{C}$ $=50 \% \mathrm{RDF}+\mathrm{RDC}(10$ ton/ha $)+$ dolomite $(4$ ton/ha $) ; \mathrm{D}=50 \% \mathrm{RDF}+\mathrm{RDC}(10$ ton/ha $)+$ chicken manure (10 ton/ha).

*** Values within the same row followed by the same letters are not significantly different at the 0.05 probability level based on Fisher protected least significant difference (LSD) test.

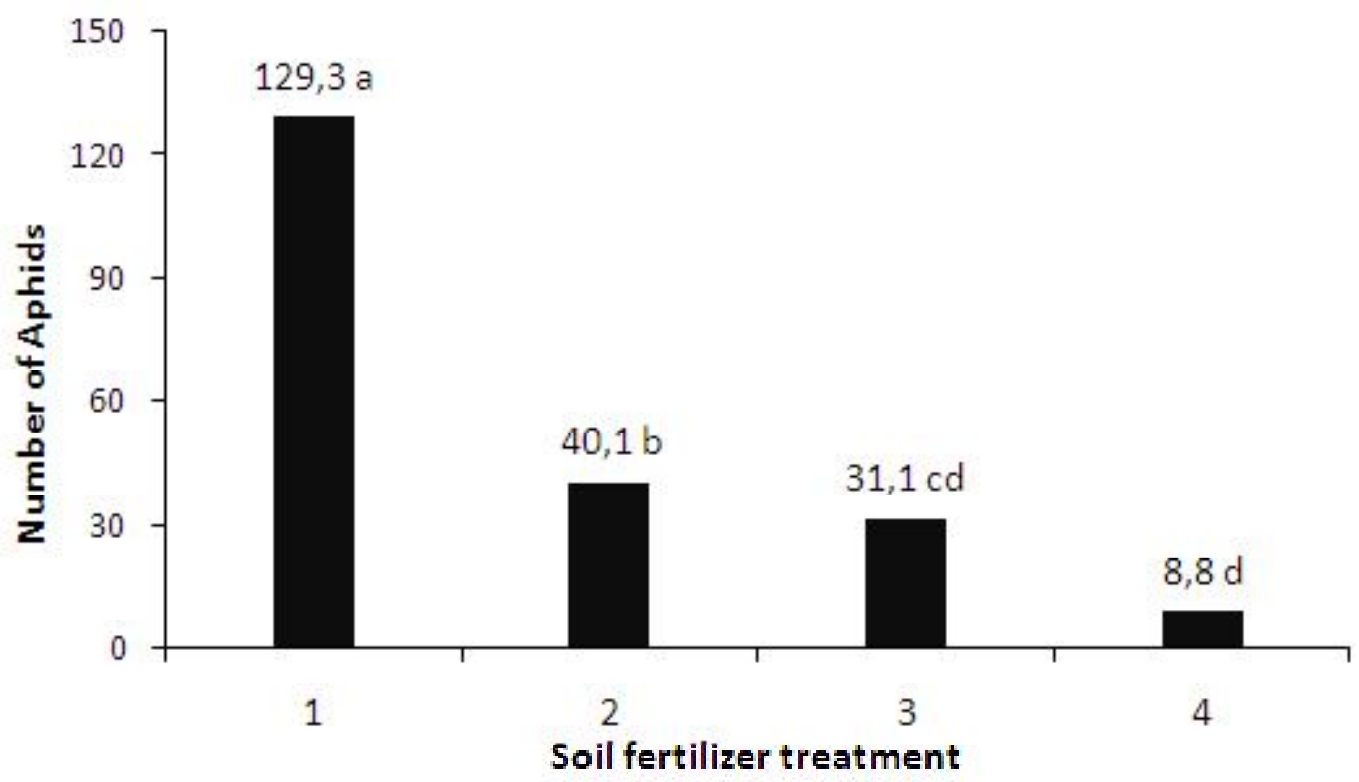

Figure 2. Common mean number soybean aphids per plant treated with different soil fertilizer: $1=100 \% 100 \%$ Recommended Dose of Fertilizer (RDF) NPK (100 kg urea/ha + $200 \mathrm{~kg} \mathrm{SP}-36 / \mathrm{ha}+200 \mathrm{~kg} \mathrm{KCl} / \mathrm{ha}) ; 2$ $=75 \% \mathrm{RDF}+$ Recommended Dose of Compost $(\mathrm{RDC}=20$ ton/ha $) ; 3=50 \% \mathrm{RDF}+\mathrm{RDC}(10$ ton/ha $)$ + dolomite (4 ton/ha); $4=50 \% \mathrm{RDF}+\mathrm{RDC}$ (10 ton/ha) + chicken manure (10 ton/ha). Means bearing the same letter are not significantly different at the 5\% significance level according to Fisher protected least significant difference (LSD) test. 
Table 4. Effect of various combinations of organic and inorganic fertilizers on the soybean growth parameters

\begin{tabular}{|c|c|c|c|}
\hline Treatments & $\begin{array}{c}\text { Leaf } \\
\text { numbers/plant }\end{array}$ & $\begin{array}{c}\text { Pod } \\
\text { numbers/plant }\end{array}$ & Plant height $(\mathrm{cm})$ \\
\hline $\begin{array}{l}\mathrm{T} 1=100 \% \text { Recommend ed D ose of } \\
\text { Fertilizer }(\mathrm{RDF})^{2}\end{array}$ & $10.4 b^{1}$ & $16.6 \mathrm{c}$ & $64.6 \mathrm{~b}$ \\
\hline $\begin{array}{l}\mathrm{T} 2=75 \% \mathrm{RDF}+\mathrm{Recommended} \text { Dose } \\
\text { of Compost }(\mathrm{RDC})^{3}\end{array}$ & $17.3 \mathrm{a}$ & $32.9 b$ & $79.4 \mathrm{a}$ \\
\hline $\begin{array}{l}\mathrm{T} 3=50 \% \mathrm{RDF}+50 \% \mathrm{RDC}+\text { Dolomite } \\
(\mathrm{Dol})^{4}\end{array}$ & $14.0 \mathrm{a}$ & $47.8 \mathrm{ab}$ & $71.0 \mathrm{ab}$ \\
\hline $\begin{array}{l}\mathrm{T} 4=50 \% \mathrm{RDF}+50 \% \mathrm{RDC}+\text { Chicken } \\
\text { Manure }(\mathrm{CM})^{5}\end{array}$ & $14.3 \mathrm{a}$ & $52.8 \mathrm{a}$ & $77.4 \mathrm{a}$ \\
\hline$P>\mathrm{F}$ & 0.0119 & 0.0023 & 0.0293 \\
\hline
\end{tabular}

1) Means within the same column followed by the same letter are not significantly different $(P=0.05)$ according to Fisher protected least significant difference (LSD) test using PROG GLM Procedure of SAS (SAS Institute Inc., 1988); ${ }^{2)} \mathrm{RDF}=$ Recommended Dose of Fertilizer $=$ NPK (urea $100 \mathrm{~kg} \mathrm{ha}^{-1}+$ SP-36 $200 \mathrm{~kg} \mathrm{ha}^{-1}+\mathrm{KCl} 200 \mathrm{~kg} \mathrm{ha}$ ${ }^{1)} ;{ }^{3)}$ compost rate $=20$ ton $\mathrm{ha}^{-1} ;{ }^{4)}$ dolomite rate $=4$ ton ha ${ }^{-1} ;{ }^{5}$ chicken manure rate $=10$ ton $\mathrm{ha}^{-1}$.

properties of soils. Soils with high organic matter and high biological activity generally exhibit good soil properties (Altieri \& Nicholls, 2003; Eigenbrode \& Pimentel, 1988; Magdoff \& van Es., 2000; Meyer and Root. 1996). Plants grown on organically managed soils, fertilized with manure, and compost have shown to be less favorable hosts for insect pests than plants grown on conventionally managed soils fertilized with synthetic fertilizers (Eigenbrode \& Pimentel, 1988; Phelan et al., 1995). Moreover, Phelan et al. (1995) and (1996) suggested that reduced susceptibility of plants to pests may mediated by soil fertility management. Other earlier field studies (Alyokhin \& Atlihan, 2005) showed consistent reduction in the densities of Colorado potato beetle larvae and summer-generation adults on potatoes grown in manure-amended soils. According to Myers \& Gratton (2006), densities of soybean aphids populations were significantly affected by potassium $(\mathrm{K})$ treatment. Low $\mathrm{K}$ levels tended to have the highest rates of soybean aphid population growth. Based on their studies, they provided a strong evidence that variation in K plays an important role in influencing soybean aphid population dynamics. Meanwhile, Hu et al. (1992) found that there was a relationship between the nitrogen content in soybean leaves and occurrence degree of $A$. glycines. Soybean aphid populations increased as nitrogen content in leaves increased and vise versa.

In addition to soybean aphid population, the effects of soil fertilizer on plant growth parameters were also recorded. The results of this study demonstrated that soil nutrition treatments had significant effects on the soybean plant performances: leaf numbers $\left(F_{3,8}=7.13\right.$; $P<0.0119)$; pod numbers $\left(F_{3,8}=12.24 ; P<0.0023\right)$ and plant height $\left(F_{3,8}=5.09 ; P<0.0293\right)$. Soybean plants fertilized with $100 \%$ recommended dose of fertilizer $(\mathrm{RDF}=\mathrm{NPK})$ had 10.33 leaves/plant in average and this number was significantly lower than that of other treatments: 17.33 leaves at $75 \% \mathrm{RDF}+\mathrm{RDC} ; 14.67$ leaves at $50 \% \mathrm{RDF}+50 \%$ recommended dose of compost (RDC) + dol., and 14.00 leaves at 50\% RDF level + 50\% RDC + CM (LSD = 3.5225; $\mathrm{P}<0.05)$ (Table 4). Moreover, pod numbers of soybean plant fertilized with $50 \% \mathrm{RDF}+50 \% \mathrm{RDC}+\mathrm{CM}$ treatment (52.67 pods/plant) were significantly higher than that of $75 \% \mathrm{RDF}+\mathrm{RDC}$ treatment (33.00 pods/plant) and $100 \%$ RDF treatment (16.67 pods/plant), however no significantly difference (48.00 pods) with $50 \% \mathrm{RDF}+$ $50 \% \mathrm{RDC}+$ dol. treatment $(\mathrm{LSD}=15.17 ; \mathrm{P}=<0.05)$. Meanwhile, plant height of soybean fertilized with $50 \%$ $\mathrm{RDF}+50 \% \mathrm{RDC}+\mathrm{CM}$ treatment was $79.33 \mathrm{~cm}$ and this height was significantly taller than that of $100 \%$ RDF $(64.33 \mathrm{~cm})(\mathrm{LSD}=9.17 ; \mathrm{P}<0.05)$, but lack of significant differences when compared to $50 \%$ NPK level + 50\% RDC + dol. $(73.33 \mathrm{~cm})$ and $50 \% \mathrm{RDF}$ level $+50 \% \mathrm{RDC}+\mathrm{CM}$ treatments $(79.33 \mathrm{~cm})($ Table 4).

The results of this study confirm that the form of fertilization input can significantly influence the plant growth. Moreover, this finding suggest that decreasing synthetic fertilizer NPK by $50 \%$ can be compensated by natural organic materials such as composts and chicken manure. Umoetok et al. (2002) found similar 
results which indicated that both NPK and poultry manure significantly affected the plant height, number of pods per plant of soybean plants. In more detail, their results explained that the plant height and pod numbers was significantly higher when inorganic fertilizer NPK was combined with poultry manure. The combination of inorganic fertilizer, compost, and chicken manure has a reasonable nutrient balance in the soils in which would be available for the soybean uptake (Myers et al., 2005; Pedersen, 2004; Magdoff \& van Es, 2000). Past study by Karungi et al. (2006) showed that plant's biomass production gaining from composted soils was comparable and sometimes even higher than those NPK treatments. Other previous studies suggested that indicated that plants that received organic fertilizer had higher above ground biomass accumulation compared with those with synthetic fertilizers (Hsu et al. (2009). Moreover, the study by Altieri and Nicholls (2003) showed that soil fertility management can have several effects on plant quality, which in turn, can affect insect abundance and subsequent levels of herbivore damage.

A linear correlation analysis was performed to understand the relationship between soybean aphid population and plant nutrients and the results were presented in Fig. 3. Number of soybean aphids, $A$. glycines, was negatively correlated with plant variables: plant height, number of leaves, and number of pods; however the significance levels among plant attributes varied. Leaf numbers was weak $(P>\mathrm{R}=0.0603)$ negatively associated with soybean aphid infestation; whereas the strong $(P>\mathrm{R}=0.0008)$ negative correlation was gained on pod numbers and aphid densities relationship (Fig. 3). This finding in which soybean aphids infestation can reduce soybean plant performance in agreement with numerous works by Myers et al. (2005); Sinclair \& de Wit (1976) who found that soybean aphid populations respond to nutrient availability in soybean. Moreover, Umoetok et al. (2002) reported that higher synthetic fertilizer inputs may lead to higher levels of insect pests of soybean (Glycine max. L.). Other previous studies indicated that soybean aphid infestations may also cause leaf yellowing and curling, plant stunting reduced branch number, lower pod and seed counts, reduced seed weight, and, under severe infestations, plant death (Blackman and Eastop, 2000; Dixon, 1977; Macedo et al., 2003; Li et al., 2000; Ragsdale et al., 2007; Wu et al., 1999). Our finding was more closely related with the works of Wang et al. (1994) who found that the number of soybean aphids per plant was negatively correlated with plant height, number of pods, and number of seeds per plant of soybean.

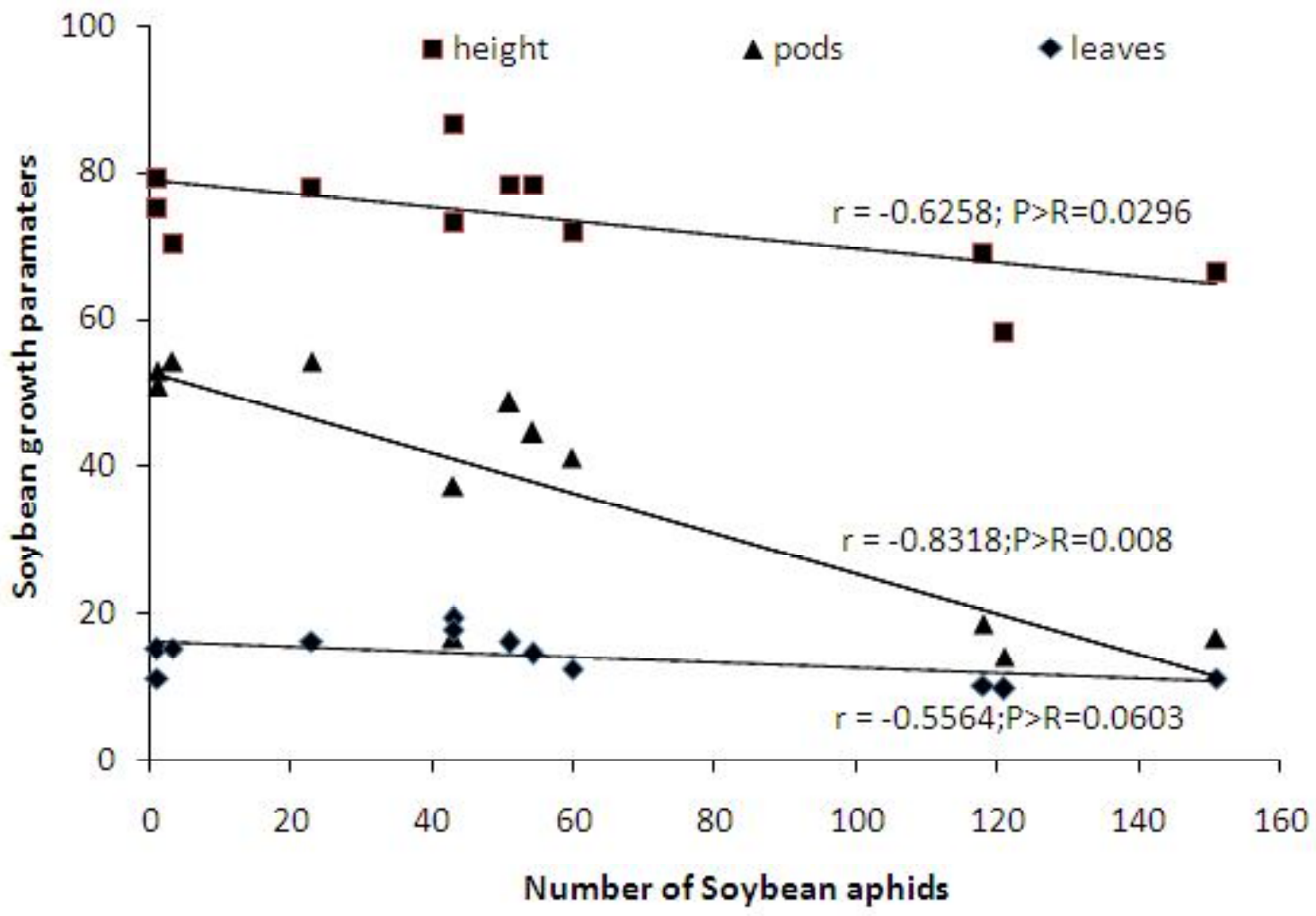

Figure 3. The relationship between soybean aphid population and the soybean growth parameters (plant height, number of leaves, and number of pods). 


\section{CONCLUSIONS}

The results of intercropping study indicated that the number of soybean aphid, population density was significantly lower on plots where soybean was intercropped with corn in comparison with those on sole soybean. There was no significant effect of intercropping on soybean plant height, number seed per pod, and weight of 1000 seeds. However the number of soybean pods per plant was significantly higher when soybean intercropped with corn. Concerning to the various results by other workers, the development of intercropping as a pest management strategy must be based on knowledge of the behavior and biology of the target pest. Meanwhile, the soil nutrition treatments had significant effects on the soybean growth: leaf numbers, pod numbers, and plant height. This finding suggest that reducing the amount of synthetic chemical fertilizer NPK can be supplemented with natural organic materials such as composts and chicken manure.

\section{ACKNOWLEDGMENTS}

We thank Widyaningrum and Giwantoro for assistance with insect colony establishment and fieldwork maintenance. This research was funded by the Strategic Grant in the year 2010 - Directorate General of Higher Education.

\section{REFERENCES}

Adeniyan ON \& Ayoola O T. 2006. Growth and yield performance of some improved soybean varieties as influenced by intercropping with maize and cassava in two contrasting locations in Southwest Nigeria. African J. Biotechnol. 5: 1886-1889.

Addo-Quaye AA, Darkwa AA \& Ocloo GK. 2011. Growth analysis of component crops in a maizesoybean intercropping system as affected by time of planting and spatial arrangement. ARPN J. Agric.l Biol. Sci. 6(6): 34-44.

Andow DA. 1991. Vegetational diversity and arthropod population response. Ann. Rev. Entomol. 36: 561568.

Alleman RJ, Grau CR \& Hogg DB. 2002. Soybean aphid host range and virus transmission efficiency, In Proceedings, Wisconsin Fertilizer, Aglime, and Pest Management, 15-17 January, Madison, WI.
Altieri MA \& Nicholls CI. 2003. Soil fertility management and insect pests: harmonizing soil and plant health in agroecosystems. Soil and Tillage Research 72:203-211.

Alyokhin A \& Atlihan R. 2005. Reduced fitness of the Colorado potato beetle on potato plants grown in manure-amended soil. Environ. Entomol. 34: 963-968.

Asman K, Ekbom B \& Rämert B. 2001. Effect of intercropping on oviposition and emigration behavior of the leek moth (Lepidoptera: Acrolepiidae) and the diamondback moth (Lepidoptera: Plutellidae). Environ. Entomol. 30: 288-294.

Bach CE. 1980. Effects of plant diversity and time of colonisation on an herbivore plant interaction. Oecologia 44: 319-326.

Biabani A, Hashemib M \& Herbert SJ. 2008. Agronomic performance of two intercropped soybean cultivars. Int. J. of Plant Production 2 (3): 215222.

Blackman RL \& Eastop VF. 2000. Aphids on the Worlds Crops: an identification and information guide. Wiley, New York.

Booij CJH, Noorlander J \& Theunissen, J. 1997. Intercropping cabbage with clover: Effects on ground beetles. Biol. Agricul. and Hort. 15: 261268.

Carruthers K, Fe Q, Cloutier D \& Smith DL. 1998. Intercropping corn with soybean, lupin and forages: yield component responses. European J. of Agronomy. 8 (3-4): 225-238.

Clark AJ \& Perry KL. 2002. Transmissibility of field isolates of soybean viruses by Aphis glycines. Plant Dis. 86: 1219-1222.

Dixon AFG. 1977. Aphid ecology: life cycle, polymorphism, and population regulation. Аnnu. Rev. Ecol. Syst. 8: 329-353.

Egbe OM. 2010. Effects of plant density of intercropped soybean with tall sorghum on competitive ability of soybean and economic yield at Otobi, Benue State, Nigeria. J. Cereals \& Oilseeds 1:1-10.

Eigenbrode SD \& Pimentel D. 1988. Effects of manure and chemical fertilizers on insect pest populations on collards. Agric. Ecosyst. Environ. 20: 199125. 
Elton CS. 1958. The Ecology of Invasions by Plants and Animals. Methuen and Co., London, England. 209 pp.

Fehr WR \& Caviness CE. 1977. Stages of Soybean Development, pp. 1-11, Special Report 80. Iowa State University Co-op Extension Service, Ames, IA.

Herbert SJ, Putnam DH, Poos-Floyd M, Vargas A \& Creighton JF, 1984. Forage yield of intercropped corn and soybean in various planting patterns. Agron. J. 76: 507-510.

Halbert SE, Zhang GX \& Pu ZQ. 1986. Comparison of sampling methods for alate aphids and observation on epidemilogy of soybean mosaic virus in Nanjing, China. Ann. Appl. Biol. 109:473483.

Hayder G, Mumtaz SS, Khan A \& Khan S. 2003. Corn and soybean intercropping under various levels of soybean seed rates. Asian J. of Plant Sci. 2:339-341.

Hill JH, Alleman HR, Hogg B \& Grau CR. 2001. First report of transmission of Soybean mosaic virus and Alfalfa mosaic virus by Aphis glycines in the New World. Plant Dis. 85:561.

Hodgson EW, VanNostrand G \& O’Neal ME. 2010. 2010 yellow book: report of insecticide evaluation for soybean aphid. Department of Entomology, Iowa State University, Publication 287-10.

Hsu YT, Shen TC \& Hwang SY. 2009. Soil Fertility Management and Pest Responses: A Comparison of Organic and Synthetic Fertilization. J. Econ. Entomol. 102: 160-169.

Hu Q, Zhang W, Yao Y \& Yan S. 1992. The relationship between the nitrogen content in soybean leaves and occurrence degree of Aphis glycines Matsumura. J. Jilin Agric. Univ. 14: 103-104.

Irwin ME. Ruesink, WG, Isard SA \& Kampmeier GE. 2000. Mitigating epidemics caused by nonpersistently transmitted aphid-borne viruses: the role of pliant environment. Virus Research 71:185-211.

Jankowska B. 2007. Impact of intercropping white cabbage with Pot Marigold (Calendula officinalis L.) and French Marigold (Tagetes patula nana) on the occurrence of cabbage aphid (Brevicoryne brassicae L.), its parasitoid
Diaeretiella rapae M'Intosh and predatory Syrphidae. Aphids and Other Hemipterous Insects 13: 199-209.

Jankowska B, Poniedzia³ek M \& Jêdrszcz E. 2009. Effect of intercropping white cabbage with French Marigold (Tagetes patula nana L.) and Pot Marigold (Calendula officinalis L.) on the colonization of plants by pest insects. Ann. Folia Horticulturae 21 (1): 95-103.

Karungi J, Ekbom B \& Kyamanywa S. 2006. Effects of organic versus conventional fertilizer on insect pests, natural enemies and yield of Phaseolus vulgaris. Ag. Eco. \& Environ. 115:51-55.

Landis DA, Wratten SD \& Gurr GM. 2000. Habitat management to conserve natural enemies of arthropod pests in agriculture. Ann. Rev. Entomol. 45:175-201

Langer V, Kinane J \& Lyngkjær M. 2007. Intercropping for pest management: The ecological concept. In: Ecologically Based Integrated Pest Management. Koul, O \& Cupreus, GW (eds.), Cabi Publishing, Wallingford, UK.

Latheef MA, Ortiz J \& Sheikh AQ. 1984. Influence of intercropping on Phyllotreta cruciferae (Coleoptera: Chrysomelidae) populations on collard plants. J. Econ. Entomol. 77: 1180-1184.

Letourneau DK, Drinkwater LE \& Shennan C. 1996. Effects of soil management on crop nitrogen and insect damage in organic vs. conventional tomato fields. Agric.Ecosyst. Environ. 57: 179-187.

Letourneau DK \& Goldstein B. 2001. Pest damage and arthropod community structure in organic vs. conventional tomato production in California. $J$. Appl. Ecol. 38: 557-570.

Li C, Luo R , Yang C, Shang Y, Zhao J \& Xin X. 2000. Studies on the biology and control of Aphis glycines. Soyb. Sci. 19: 337-340.

Macedo TB, Bastos CS, Higley LG, Ostlie KR \&Madhavan S. 2003. Photosynthetic responses of soybean to soybean aphid (Homoptera: Aphididae) injury. J. Econ. Entomol. 96: 188193.

Magdoff F \& van Es H. 2000. Building Soils for Better Crops. Sustainable Agriculture Research and Education, Washington, DC. 
McCornack BP, Costamagna AC \& Ragsdale DW. 2008. Within-Plant Distribution of Soybean Aphid (Hemiptera: Aphididae) and Development of Node-Based Sample Units for Estimating WholePlant Densities in Soybean. J. Econ. Entomol. 101(4): 1488-1500.

Mensah GWK. 1997. Integrated Pest Management in cowpea through intercropping and minimal insecticide application. Annals. of Plant Protec. Sci. 5:1-14.

Meyer GA \& Root RB. 1996. Influence of feeding guild on insect response to host plant fertilization. Ecol.Entomol. 21: 270-278.

Myers SW \& Gratton C. 2006. Influence of Potassium Fertility on Soybean Aphid, Aphis glycines Matsumura (Hemiptera: Aphididae), Population Dynamics at a Field and Regional Scale. Environ. Entomol. 35: 219-227.

Myers SW, Hogg DB \& Wedberg JL. 2005. Determining the optimal timing of foliar insecticide applications for control of soybean aphid (Hemiptera: Aphididae) on soybean. J. Econ. Entomol. 98: 2006-2012.

Ofori F \& Stern WR.1987. Cereal-legume intercropping systems. Adv. Agron. 41: 41-90.

Oso AA \& Falade MJ. 2010. Effects of Variety and Spatial Arrangement on Pest Incidence,Damage and Subsequent Yield of Cowpea in a Cowpea/ Maize Intercrop. World J. of Agricultural Sci. 6 (3): 274-276.

Pedersen, P. 2004. Soybean growth and development. Iowa State University, University Extension, Ames, IA

Phelan PL, Mason JF \& B Stinner R. 1995. Soil fertility management and host preference by European corn borer, Ostrinia nubilalis (Hubner), on Zea mays L.: a comparison of organicandconventional chemical farming. Agric. Ecosyst. Environ. 56: 1-8.

Phelan PL, Norris KH, \& Mason JF. 1996. Soil management history and host preference by Ostrinia nubilalis: evidence for plant mineral balance mediating insect- plant interactions. Environ. Entomol. 25: 1329-1336.
Qu YX, Ma ZQ, Shan DA, Gao XH, \& Wang QS. 1987. Effects of insecticides on population of destructive insects and their natural enemies in the soybean field. Plant Prot. 13: 4 - 6.

Ragsdale DW, McCormack BP, Venette RC, Potter BD, MacCrae IV, Hodgson EW, O'NeaL ME, Johnson KD, O’Neil RJ, Difonzo CD, Hunt TE, Glogaza PA, \& E. . Cullen M. 2007. Economic threshold for soybean aphid (Hemiptera: Aphididae). J. Econ. Entomol. 100: 1258-1267.

Raji JA. 2007. Intercropping soybean and maize in a derived savanna ecology. African J. Biotech. 6: 1885-1887.

Ramalho FS, Fernandes FS, Nascimento ARB, Nascimento JL, Malaquias JB \& Silva. 2012. Assessment of Fennel Aphids (Hemiptera: Aphididae) and Their Predators in Fennel Intercropped With Cotton With Colored Fibers . J. Econ. Entomol. 105: 113-119.

Risch SJ. 1983. Intercropping as cultural pest control: prospects and limitations. Environ. Manag. 7: 9-14.

Root R. 1973. Organisation of a plant-arthropod association in simple and diverse habitats. The fauna of collards (Brassica oleracea). Ecological Monographs 43: 95-124.

Russell EP. 1989. Enemies hypothesis: a review of the effect of vegetational diversity on predatory insects and parasitoids. Environ. Entomol. 18: 590-599.

SAS Institute. 2004. SAS/STAT User of Guide, version 6.12. SAS Institute, Cary, NC.

Sinclair TR \& de Wit CT. 1976. Analysis of the carbon and nitrogen limitations to soybean yield. Agron. J. 68: 319-324.

Theunissen J \& Den Ouden H. 1980. Effects of intercropping with Spergula arvensis on pests of Brussels sprouts. Entomol. Exp. Appl. 27: 260268.

Umoetok SBA, Uko AE, Archibong BE, Ukeh DA \& Udo IA. 2002. Effect of application of inorganic fertilizer and poultry manure on insect pests and yield of soybean (Glycine max L.) in the rain forest zone of Nigeria. Entomol. Experim. Appl.104:109-116. 
van den Berg H, Ankasah D, Mahammad A, Rusli R, Widayanto HA, Wirasto HB \& Yully I. 1997. Evaluating the role of predation in population fuctuations of the soybean aphid Aphis glycines in farmer fields in Indonesia. J. Appl. Ecol. 34: 971-984.

Vandermeer, J. 1989. The Ecology of Intercropping. Cambridge University Press, Cambridge, UK.

Wang RY \& Ghabrial SA. 2002. Effect of aphid behavior on efficiency of transmission of Soybean mosaic virus by the soybean-colonizing aphid, Aphisglycines. Plant Dis. 86: 1260-1264.

Wang, XB, Fang YH, Lin SZ, Zhang LR, \& Wang HD. 1994. A study on the damage and economic threshold of the soybean aphid at the seedling stage. Plant Prot. 20: 12-13

Wang S, Shen DA \& Ma ZQ. 1993. Insecticide influence on populations of major insect pests and natural enemies at the soybean seedling stage. Entomol. Knowl. 30: 333-335.
Whigham DK \& Bharati MP. 1983. Soybean sole cropping and intercropping in Temperate and Subtropical Environments. In soybean in Tropical and Subtropical Cropping Systems. Proceedings of a symposium Tsukuba, Japan. pp. 137-147.

Wiley RW \& Osiru DSO. 1972. Studies on mixtures of maize and beans with particular reference to plant populations. J. Agri. Sci. 79:517-529.

Wu, XB, Ni WJ, \& Liu P . 1999. Occurrence and control of the soybean aphid, Aphis glycines Matsumura. Chin. J. Biol. Control 6: 20

Wu Z, Schenk-Hamlin D, Zhanb W, Ragsdale DW, \& Heimpel GE. 2004. The soybean aphid in China: ahistorical review. Ann. Entomol. Soc. Am. 97: 209-218.

Xie H, Ju-Lian C, Deng-Fa C, Zhou H, Jing-Rui S, Yong L \& Frédéric F. 2012. Impact of WheatMung Bean Intercropping on English Grain Aphid (Hemiptera: Aphididae) Populations and Its Natural Enemy. J. Econ. Entomol. 105: 854859. 